\title{
MITIGATION OF SALINITY STRESS OF PEPPER (CAPSICUM ANNUUM L.) BY ARBUSCULAR MYCORRHIZAL FUNGUS, GLOMUS CONSTRICTUM
}

\author{
AL-AMRI, S. M \\ Department of Biology, College of Science and Art, Shaqra University, Shaqra, Saudi Arabia \\ (e-mail:phd1618@hotmail.com,abdelfattaham@yahoo.com) \\ (Received $8^{\text {th }}$ Apr 2019; accepted $13^{\text {th }}$ Jun 2019)
}

\begin{abstract}
A pot experiment was investigated to study the effect of arbuscular mycorrhizal (AM), Glomus constrictum (Trappe) on growth response, photosynthetic pigments, gas exchange parameters, antioxidant enzymes and nutrition of pepper plants irrigated with different concentrations of sea water. Four concentrations (tap water, 10\%, 20\% and $40 \%$ of sea water) were used. Salinity stress markedly reduced all studied parameters, except antioxidant enzymes, of pepper plants. Under saline conditions, AM fungi significantly increased growth parameters, photosynthetic pigments, nutrient contents (except $\mathrm{Na}^{+}$), gas exchange rate and antioxidant enzymes of pepper plants when compared to non-mycorrhizal ones. Those improvements were linked to mycorrhizal infection degree in pepper. Generally, growth, nutrition, photosynthetic pigments and antioxidant enzymes of pepper appeared to be highly dependent on the AM in salinized soil compared to non-salinized soil. This study suggested that mycorrhizal colonization could be used to mitigate the detrimental effects of salinity, particularly in soils irrigated with high concentration of sea water.
\end{abstract}

Keywords: salinity, mycorrhiza, growth, pepper, antioxidant enzymes

Abbreviations: $P_{N}$ : net photosynthetic rate; AM: arbuscula rmycorrhizal; AMF: arbuscular mycorrhizal fungi; AMR: arbuscula rmycorrhizal response; Dwt: dry weight; Fwt: fresh weight; $E$ : transpiration rate; $g_{\mathrm{s}}$ : stomatal conductance; LA: leaf area; Non-AMF: non-arbuscular mycorrhizal fungi; N: nitrogen; P: phosphorus; K: potassium; Na: sodium; Mg: magnesium; $\mathrm{Ca}-$ calcium; CAT: catalase; POX: peroxidase; APX: ascorbate peroxidase.

\section{Introduction}

Water salinity is a very important environmental problem, particularly in Saudi Arabia, decreasing plant growth and yields worldwide, and affecting about $10 \%$ of the world's global land (Abdel-Ghani, 2009; Al-Amri et al., 2013; Abdel-Fattah et al., 2016). The saline area is still extending due to irrigation and land clearing (AbdelFattah et al., 2013; Sheng et al., 2013). Increasing salt concentration in soil suppresses the plant ability to absorb and uptake water, negatively decreases metabolic processes, nutrient absorbance, root hydraulic conductivity and all photosynthetic rates, all of these results in negatively affecting the plant ability to grow (Al-Karaki et al., 2001; AbdelFattah and Asrar, 2012).

Pepper (Capsicum annuum L.) is an important vegetable plant in Saudi Arabia. Raising growth of pepper plant through improving the productivity area as increasing the cultivated area in salinized newly reclaimed lands is the major important national target. Increasing salt tolerance of vegetables, horticultures and economic plants is required to tolerate the increase in food production in many regions of the world in general and Saudi Arabia in particular (Al-Amri et al., 2013). Expansion of salt-tolerant vegetables or desalinization of soil by washing excessive salts in not enough to remove this problem (Kumar et al., 2010; Abdel-Fattah et al., 2016). Recently, application of biological agents like mycorrhizal symbiosis as a practical applied technology to 
mitigate salt stress effects on plant growth and development has customary a great attention (Poss et al., 1985; Abdel-Fattah and Asrar et al., 2012; Al-Amri et al., 2013).

Several investigators have concluded that the existence of the arbuscular mycorrhizal plants grown in saline stress conditions (Pond et al., 1984; Kumar et al., 2010; Wu et al., 2010; Asrar et al., 2014). Furthermore, the biotechnological application of arbuscular mycorrhizal fungi in salinized soil may increase plant tolerance and growth via mitigating the adverse effect of salt stress in various plants (Juniper and Abbott, 1993; Daei et al., 2009; Abdel-Fattah and Asrar, 2012). Under salinity stress conditions, plant tolerance and production are complicated different mechanisms. In this connection, arbuscular mycorrhizal fungi has several mechanisms to increase salt tolerance of associated plants through stimulating nutrient uptake (Evelin et al., 2009; Abdel-Fattah et al., 2013); decreasing the uptake of $\mathrm{Na}+$ and preventing their movement to aerial parts of plant (Daei et al., 2009); increasing water uptake (AlKaraki, 2006; Asrar et al., 2012); maintaining ionic balance by increasing and/or selective uptake of nutrients (Kumar et al., 2010); increasing of some antioxidant defense enzyme activities (catalase, peroxidase, superoxide dismutase and ascorbate peroxidase) and molecules like carotenoids, glutathione and tocopherols (Ibrahum et al., 2011); accumulating of polyamines like spermine and spermidine in associated host plants and regulating the osmotic status of plants through maintaining the turgor pressure of the leaves, and stimulating the photosynthetic and transpiration rate, and water use efficiency in the host plants (Juniper and Abbott, 2006; Auge et al., 2008).

Due to the detrimental effects of salt stress on different plants species and the function of arbuscular mycorrhizal fungi in improving the salinity tolerance, the present study was evaluated to study the efficiency of arbuscular mycorrhizal fungus (Glomus constrictum, Trappe) for enhancing plant growth, photosynthetic pigments, nutrition, gas exchange and some antioxidant enzymes of Pepper plants grown in soil irrigated with different concentrations of sea water.

\section{Materials and methods}

\section{Experimental design}

The experiment with a $(2 \times 4)$ factorial design was done. The treatments consisted of two arbuscular mycorrhizal onces [Glomus constrictum (AMF) and non-inoculated (-AMF)] and four levels $\{0.0 \%$ (control), $15 \%, 30 \%$ and $60 \%$ of sea water $\} \mathrm{g} \mathrm{Kg}^{-1}$ and $0.5 \mathrm{~g} \mathrm{~kg}^{-1}$ soil]. The sea water was obtained from the Red sea, Gadda, Saudi Arabia. Each of the eight treatments was replicated ten times (one plant per each pot) to give 90 pots as total.

\section{Inoculum preparation of arbuscular mycorrhizal fungus}

The inoculums mycorrhizal fungus, Glomus constrictum (Trappe), was isolated from saline site of Shaqra region using the wet sieving method of Gerdmann and Nicolson (1963). The spores of AM were left to multiply for 4 monthes in greenhouse under controlled environmental conditions. The mycorrhizal inoculums consisting of $10 \mathrm{~g}$ of rhizoplane soil (approx. 600 spores) and $0.5 \mathrm{~g}$ of colonized onion root pieces with a colonized level of $80 \%$ were inoculated to each pot. The mycorrhizal inoculums were added at $5 \mathrm{~cm}$ depth the pepper seedlings upon planting. 


\section{Plant and growth conditions}

Seeds of Pepper (Capsicum annuum L.) were surface disinfected by soaking in $7 \%$ sodium hypochlorite for $10 \mathrm{~min}$ then rewashed with deionized sterilized water and left to germinate for $48 \mathrm{~h}$ on wetted sterilized filter paper in dark at $25^{\circ} \mathrm{C}$. Similar sterilized germinated seedlings were transplanted (one plant/pot) into $20 \mathrm{~cm}$ diameter plastic pots containing $3 \mathrm{~kg}$ of autoclaved $\left(120^{\circ} \mathrm{C}\right.$ for 3 separate consequent time) sandy loam soil. Soil characteristics were: $\mathrm{pH}$ (water) $=7.31$; available nitrogen $\left(15.0 \mathrm{mg} \mathrm{kg}{ }^{-1}\right)$; available phosphorus (5.12 mg kg$\left.{ }^{-1}\right)$; potassium $\left(40 \mathrm{mg} \mathrm{kg}^{-1}\right)$; magnesium $\left(53 \mathrm{mg} \mathrm{kg}^{-1}\right)$ and organic matter $(0.33 \%)$. All pots were irrigated by tap water (control) until the second week, and then the pots were divided into four groups for salinity treatments. The $1^{\text {st }}$ group irrigated with tap water (control), the $2^{\text {nd }}, 3^{\text {rd }}$ and $4^{\text {th }}$ groups were irrigated with 15,30 and $50 \%$ sea water respectively. Chemical analysis of sea water are: $\mathrm{Cl}^{-}$, $21.5 \mathrm{~g} / \mathrm{l} ; \mathrm{Na}^{+}, 12.5 \mathrm{~g} / \mathrm{l} ; \mathrm{K}^{+}, 0.49 \mathrm{~g} / \mathrm{l}$; salinity, $38.2 \mathrm{~g} / \mathrm{kg} ; \mathrm{pH} 8.2$ and its electrical conductivity was $48 \mathrm{mmhos} / \mathrm{cm}$. Half of all pots treated or non-treated with different concentrations of sea water were inoculated with the mycorrhizal fungus, Glomus constrictum (as described before). Arbuscular mycorrhizal inoculums were added $3 \mathrm{~cm}$ below the seedlings at planting time. The non-mycorrhizal treatments (-AMF) were provided with filtered washings of an equal amount of the mycorrhizal soil inoculum to provide the same associated microorganisms without AM spores. All pots were arranged in a complete randomized blocks design in a glasshouse of Experimental Station of Plant Production Department, College of Food and Agriculture Sciences, King Saud University under controlled conditions of $550 \mu \mathrm{mol} \mathrm{m} \mathrm{m}^{-2} \mathrm{~s}^{-1}$ light intensity, $23 / 18{ }^{\circ} \mathrm{C}$ day/night temperatures, $70-80 \%$ relative humidity and 16 -h photoperiod. Plants for all treatments received $32 \mathrm{mg}$ sulfur $\left(\mathrm{K}_{2} \mathrm{SO}_{4}\right) \operatorname{pot}^{-1}$ as a nutrient solution after four weeks of planting. All plants were watered regularly with the corresponding irrigation sea water level. Ten plants for each treatment were harvested 10 weeks after planting.

\section{Growth parameters}

At harvest, the plants for each harvest were carefully uprooted with minimum disturbance of roots. The roots were washed with tap water to remove adherent soil particles and the shoot height per plant was measured. Roots and shoots fresh and dry weights (after drying the samples at $80{ }^{\circ} \mathrm{C}$ for $48 \mathrm{~h}$ in oven) were recorded. Leaf area was determined using a leaf area meter (Li-Cor, Lincoin, NE). Arbuscular mycorrhizal growth responses (AMR) for each estimated parameter was calculated following Menge et al. (1978) using the following formula: (parameter value of mycorrhizal treatment (AMF) - parameter value of non-mycorrhizal treatment $(-\mathrm{AMF}) /\{$ parameter value of non-mycorrhizal treatment $(-\mathrm{AMF})\} \times 100$.

\section{Estimation of photosynthetic pigments}

Photosynthetic pigments content (chlorophyll 'a', and "b", carotenoids and total pigments) of the fully mature third leaves for each treatment was determined by extraction in $85 \%$ aqueous acetone for $5 \mathrm{~min}$. The homogenate samples were centrifuged at $8000 \mathrm{rpm}$ for $10 \mathrm{~min}$. The supernatant was made up to $10 \mathrm{ml}$ with acetone and it measured spectrophotometrically against a blank of aqueous acetone The concentrations of the pigments were determined using the equations of Abdel-Fattah et al. (2013). 


\section{Measurement of photosynthesis, transpiration and stomatal conductance}

Net photosynthetic rate $(A)$, transpiration rate $(E)$ and stomatal conductance $\left(g_{\mathrm{s}}\right)$ of the mature third leaves were measured by using Li-Cor, 8400XT, Lincoln. NE, USA. Leaf was fitted into leaf chamber. Gas exchange measurements were made in the growth chamber under saturated light conditions and adjusted to an intensity of $480 \mu \mathrm{mol} \mathrm{m}{ }^{-1} \mathrm{~s}^{-1}$. Four replicates for each treatment were used.

\section{Nutrient analysis}

Root and shoot samples for each tratment were oven-dried, grounded. A known weight of the dried material was extracted in a digestion flask containing $10 \mathrm{ml}$ of three acid mixture $\left(\mathrm{HNO}_{3}: \mathrm{H}_{2} \mathrm{SO}_{4}: 60 \% \mathrm{HCL}\right.$, at the ratio of $3: 2: 1(\mathrm{v} / \mathrm{v} / \mathrm{v})$, respectively) in kjeldahed digestion flask. Phosphorus $(\mathrm{P})$ was determined by the vanadate-molybdate colorimetric method (Jackson, 1973). Calcium $\left(\mathrm{Ca}^{++}\right)$, potassium $\left(\mathrm{K}^{+}\right)$, magnesium $\left(\mathrm{Mg}^{++}\right.$and sodium $\left(\mathrm{Na}^{+}\right)$in digested samples by using atomic absorption (model unicam 969). Total nitrogen (N) was analyzed using Kjeldahl method (Nelson and Sommers 1973).

\section{Estimation the activities of antioxidant enzymes (Catalase, peroxidase andascorbate peroxidase)}

Antioxidant enzymes were analyzed by homogenization of a known leaf fresh weight in $50 \mathrm{mM}$ cold phosphate buffer (pH 7.0) containing $1 \mathrm{mM}$ EDTA (Ethylene Diamine tetra acetic acid) and $5 \mathrm{mM}$ ascorbic acid in case of ascorbate peroxidase assay (Gajewska and Sklodowska, 2008). Peroxidase (POX) and Catalase activitties (CAT) were estimated according to the method of Aebi (1983). The specific enzyme activity of CAT and POX was expressed as $\mu \mathrm{mol}$ of $\mathrm{H}_{2} \mathrm{O}_{2}$ consumed/min. Ascorbate peroxidase (XPX) activity was assayed using the method of Nakano and Asada (1981) and the specific activity of this enzyme was expressed as $\mu \mathrm{mol}$ oxidized ascorbate $/ \mathrm{min}$.

\section{Mycorrhizal colonization}

After harvest, the root systems for each treatment were washed carefully with tap water to remove all the adhering soil particles. Randomly sampled roots from five plants per treatment were cut into 0.5 to $1 \mathrm{~cm}$ pieces, then cleared with $10 \% \mathrm{KOH}$ solution and stained with $0.05 \%$ trypan blue in lactophenol (Phillips and Hayman, 1970) for estimated of mycorrhizal colonization. 40 root segments of each treatment were putted on slides and were examined with a light microscope (Carl Zeiss, Japan) at 40x magnification, where visually were allocated six classes of mycorrhizal colonization (from 0 to 5, depending on the occurrence of mycorrhizal structure in the root segment) and four levels of arbuscular abundance (from A0 to A3). With this values, mycorrhizal colonization levels [Frequency of mycorrhizal colonization $(\mathrm{F} \%)$, the intensity of mycorrhizal colonization ( $\mathrm{M} \%)$ and arbuscular frequency (A \%)] of the stained roots were estimated according to Trouvelot et al. (1986) using the "Mycocalc" software (http://www.dijon.inra.fr /mychintec/mycocalcprg/download.html).

\section{Statistical analysis}

All results were statistical analyzed using two-factor analysis of variance (ANOVA). Means of all treatments were divided by Duncan's multiple range tests by the least 
significant difference (LSD, $\mathrm{P} \leq 0.05)$ method using the Costat software. All of the measurements were performed five times for each treatment. The means and calculated standard error (SE) are recorded.

\section{Results}

\section{Growth responses}

Sea water stress significantly reduced biomass of shoots and roots, leaf area and shoot length of both mycorrhizal (AMF) and nonmycorrhizal (-AMF) pepper plants compared with control treatment (irrigated with tap water) and the rate of reduction increased with increasing sea water concentration in the soil. However, the reduction in most growth criteria was more pronounced in non-mycorrhizalkal pepper plants (Table 1). In this connection; Leaves of mycorrhizal pepper plants grown at higher concentrations of sea water were highly greener and less senescent than those in the non-AM plants (Fig. 1). Values of mycorrhizal dependency of pepper plants (AMR) in responding to AMF colonization were significantly increased with increasing sea water concentration in soil.
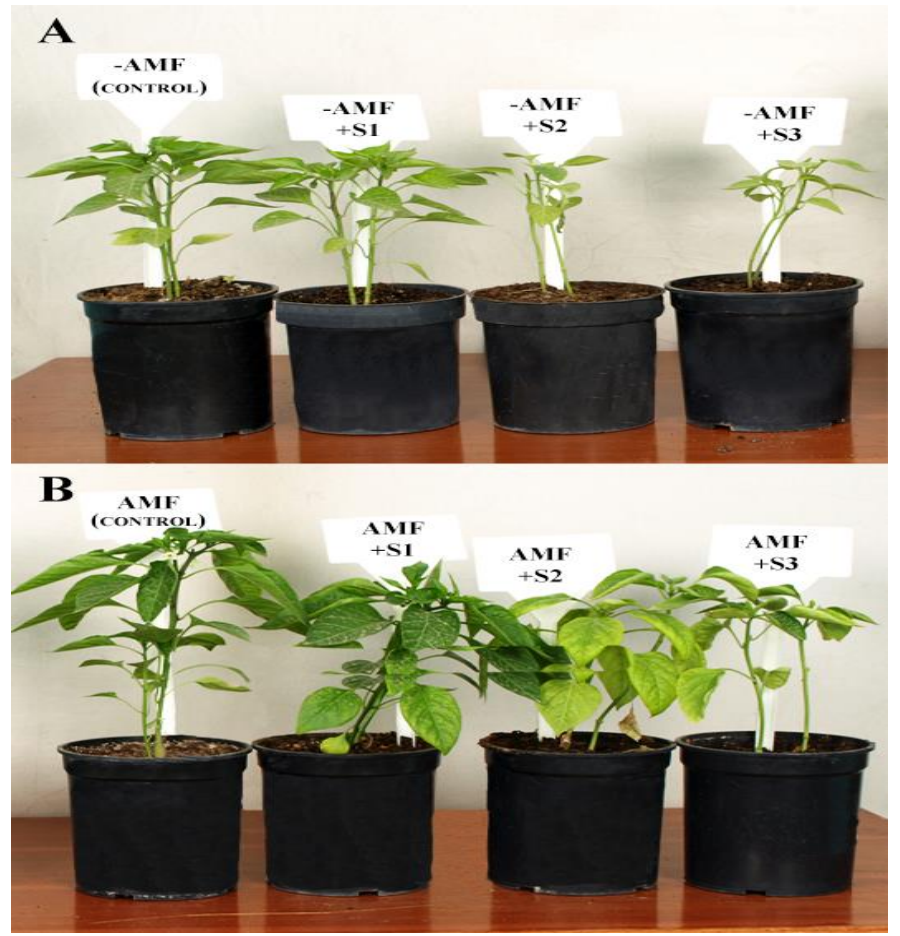

Figure 1. Growth of non-mycorrhizal (-AMF) [A] and Mycorrhizal (AMF) [B] Pepper plants grown in soil irrigated with different concentrations of sea water [Control (0.0), S1 (10\%), S2 (20\%) and S3 (40\%)]. The leaves of non-mycorrhizal pepper plants were more senescent (less green) than those of mycorrhizal plants

\section{Photosynthetic pigments}

The photosynthetic pigments content (chlorophyll a, chlorophyll $\mathrm{b}$ and carotenoids) in mycorrhizal leaves of pepper plants were significantly greater than those of nonmycorrhizal plants grown either with or without sea water irrigated in soil (Table 2). 
Such increases in these contents were linked to the degree of mycorrhizal colonization. In most cases, this increase in carotenoides content in leaves of pepper plants in response to mycorrhizal effects was increased with increasing sea water concentration in the soil, particularly $40 \%$. On contrary, no significant differences chlorophyll "b" was observed between mycorrhizal plants irrigated with $10 \%$ sea water and control treatment (Table 2).

Table 1. Growth parameters of mycorrhizal $(A M F)$ and non-mycorrhizal (-AMF) pepper plants grown in soil irrigated with different concentrations of sea water

\begin{tabular}{|c|c|c|c|c|c|c|c|}
\hline \multicolumn{2}{|c|}{ Treatments } & \multicolumn{2}{|c|}{$\begin{array}{l}\text { Fresh weight } \\
\left(\text { g plant }^{-1}\right)\end{array}$} & \multicolumn{2}{|c|}{$\begin{array}{l}\text { Dry weight } \\
\left.\text { (g plant }^{-1}\right)\end{array}$} & \multirow{2}{*}{$\begin{array}{l}\text { Shoot height } \\
\left(\mathrm{cm}_{\text {plant }}{ }^{-1}\right)\end{array}$} & \multirow{2}{*}{$\begin{array}{c}\text { Leaf area } \\
\left(\mathbf{m m}^{2} \text { plant }^{-1}\right)\end{array}$} \\
\hline $\begin{array}{l}\text { Sea water } \\
\text { conc. }(\%)\end{array}$ & AMF status & Shoot & Root & Shoot & Root & & \\
\hline \multirow{3}{*}{$\begin{array}{c}\text { Control } \\
(0.0)\end{array}$} & $-\mathrm{AMF}$ & $14.15 \pm 0.96^{\mathrm{D}}$ & $1.58 \pm 0.09^{\mathrm{B}}$ & $3.51 \pm 0.44^{\mathrm{BC}}$ & $0.84 \pm 0.05^{\mathrm{B}}$ & $28.5 \pm 1.25^{\mathrm{C}}$ & $250 \pm 8.11^{\mathrm{C}}$ \\
\hline & AMF & $18.00 \pm 0.98^{\mathrm{A}}$ & $2.01 \pm 0.17^{\mathrm{A}}$ & $4.11 \pm 0.57^{\mathrm{AB}}$ & $0.93 \pm 0.09^{\mathrm{A}}$ & $40.1 \pm 2.41^{\mathrm{A}}$ & $350 \pm 9.21^{\mathrm{A}}$ \\
\hline & $\operatorname{AMR}(\%)$ & $27.2 \pm 1.37$ & $27.1 \pm 2.09$ & $17.1 \pm 1.05^{\mathrm{B}}$ & $10.7 \pm 0.96$ & $40.7 \pm 1.95$ & $40.0 \pm 1.38$ \\
\hline \multirow{3}{*}{$10 \%$} & -AMF & $14.00 \pm 0.85^{\mathrm{D}}$ & $1.90 \pm 0.13^{\mathrm{AB}}$ & $3.21 \pm 0.45^{\mathrm{C}}$ & $0.77 \pm 0.10^{\mathrm{B}}$ & $25.3 \pm 1.05^{\mathrm{CD}}$ & $245 \pm 7.99^{\mathrm{C}}$ \\
\hline & AMF & $17.90 \pm 0.54^{\mathrm{A}}$ & $2.11 \pm 0.22^{\mathrm{A}}$ & $4.00 \pm 0.53^{\mathrm{A}}$ & $0.88 \pm 0.16^{\mathrm{AB}}$ & $39.1 \pm 2.11^{\mathrm{A}}$ & $352 \pm 9.01^{\mathrm{A}}$ \\
\hline & $\operatorname{AMR}(\%)$ & $27.90 \pm 1.97$ & $11.2 \pm 1.98$ & $24.6 \pm 1.58$ & $14.3 \pm 0.93$ & $59.5 \pm 2.99$ & $43.7 \pm 1.37$ \\
\hline \multirow{3}{*}{$20 \%$} & -AMF & $13.38 \pm 0.59^{\mathrm{D}}$ & $1.54 \pm 0.19^{\mathrm{B}}$ & $2.99 \pm 0.33^{\mathrm{CD}}$ & $0.70 \pm 0.09^{\mathrm{C}}$ & $23.2 \pm 1.08^{\mathrm{D}}$ & $238 \pm 8.04^{\mathrm{CD}}$ \\
\hline & AMF & $17.62 \pm 0.98^{B}$ & $1.93 \pm 0.21^{\mathrm{AB}}$ & $3.87 \pm 0.54^{\mathrm{B}}$ & $0.82 \pm 0.08^{\mathrm{AB}}$ & $35.1 \pm 2.11^{\mathrm{B}}$ & $340 \pm 8.62^{\mathrm{AB}}$ \\
\hline & $\operatorname{AMR}(\%)$ & $30.90 \pm 1.87$ & $25.3 \pm 1.99$ & $29.4 \pm 1.97$ & $17.1 \pm 0.83$ & $51.3 \pm 2.95$ & $42.8 \pm 1.88$ \\
\hline \multirow{3}{*}{$40 \%$} & $-\mathrm{AMF}$ & $12.10 \pm 0.89^{\mathrm{E}}$ & $0.89 \pm 0.08^{\mathrm{D}}$ & $2.11 \pm 0.55^{\mathrm{D}}$ & $0.55 \pm 0.03^{\mathrm{D}}$ & $18.8 \pm 1.01^{\mathrm{E}}$ & $200 \pm 6.25^{\mathrm{D}}$ \\
\hline & AMF & $15.99 \pm 0.54^{\mathrm{C}}$ & $1.11 \pm 0.29^{\mathrm{C}}$ & $3.28 \pm 0.58^{\mathrm{BC}}$ & $0.69 \pm 0.04^{C}$ & $29.6 \pm 1.22^{\mathrm{C}}$ & $310 \pm 8.11^{\mathrm{B}}$ \\
\hline & $\operatorname{AMR}(\%)$ & $32.20 \pm 2.01$ & $24.7 \pm 1.89$ & $55.4 \pm 2.15$ & $25.5 \pm 1.34$ & $57.4 \pm 2.95$ & $55.0 \pm 2.08$ \\
\hline
\end{tabular}

Values in each column (except AMR) followed by the same letter(s) are not significantly different at $P \leq 0.05$ (Duncan's multiple range test). AMF: arbuscular mycorrhizal fungi, -AMF: non-mycorrhizal fungi, AMR: arbuscular mycorrhizal response. Each value represents the mean of five replicates \pm standard error

Table 2. Photosynthetic pigments in leaves of mycorrhizal (AMF) and non-mycorrhizal ($A M F)$ pepper plants grown in soil irrigated with different concentrations of sea water

\begin{tabular}{|c|c|c|c|c|}
\hline \multicolumn{2}{|c|}{ Treatments } & \multicolumn{3}{|c|}{ Chlorophyll content ( $\left.\mu \mathrm{g} \mathrm{g}^{-1} \mathbf{f w t}.\right)$} \\
\hline $\begin{array}{l}\text { Sea water } \\
\text { conc. }(\%)\end{array}$ & AMF status & Chlorophyll "a" & Chlorophyll "b" & Carotenoides \\
\hline \multirow{3}{*}{$\begin{array}{c}\text { Control } \\
(0.0)\end{array}$} & $-\mathrm{AMF}$ & $830 \pm 10.22^{\mathrm{C}}$ & $400 \pm 4.22^{\mathrm{B}}$ & $680 \pm 7.22^{\mathrm{B}}$ \\
\hline & $\mathrm{AMF}$ & $1340 \pm 18.22^{\mathrm{A}}$ & $570 \pm 4.24^{\mathrm{A}}$ & $850 \pm 9.54^{\mathrm{A}}$ \\
\hline & $\operatorname{AMR}(\%)$ & $61.4 \pm 2.44$ & $42.5 \pm 0.87$ & $25.0 \pm 0.31$ \\
\hline \multirow{3}{*}{$10 \%$} & -AMF & $670 \pm 9.25^{\mathrm{D}}$ & $290 \pm 2.48^{C}$ & $450 \pm 3.99^{\mathrm{CD}}$ \\
\hline & AMF & $1050 \pm 11.47^{\mathrm{B}}$ & $480 \pm 3.99^{\mathrm{A}}$ & $530 \pm 2.41^{\mathrm{C}}$ \\
\hline & $\operatorname{AMR}(\%)$ & $56.7 \pm 1.99$ & $65.5 \pm 1.49$ & $17.8 \pm 0.27$ \\
\hline \multirow{3}{*}{$20 \%$} & -AMF & $490 \pm 7.22^{\mathrm{E}}$ & $225 \pm 1.33^{\mathrm{D}}$ & $405 \pm 4.14^{\mathrm{D}}$ \\
\hline & AMF & $620 \pm 8.71^{\mathrm{D}}$ & $290 \pm 1.30^{\mathrm{C}}$ & $.455 \pm 4.00^{\mathrm{CD}}$ \\
\hline & $\operatorname{AMR}(\%)$ & $26.5 \pm 1.05$ & $28.9 \pm 0.85$ & $12.3 \pm 0.19$ \\
\hline \multirow{3}{*}{$40 \%$} & $-\mathrm{AMF}$ & $360 \pm 4.17^{\mathrm{F}}$ & $165 \pm 0.73^{\mathrm{E}}$ & $215 \pm 2.45^{\mathrm{F}}$ \\
\hline & AMF & $400 \pm 3.58^{\mathrm{EF}}$ & $195 \pm 0.89^{\mathrm{CD}}$ & $338 \pm 2.98^{\mathrm{E}}$ \\
\hline & $\operatorname{AMR}(\%)$ & $11.1 \pm 0.84$ & $18.8 \pm 0.22$ & $57.2 \pm 1.97$ \\
\hline
\end{tabular}

Values in each column (except AMR) followed by the same letter(s) are not significantly different at $P \leq 0.05$ (Duncan's multiple range test). AMF: arbuscular mycorrhizal fungi, -AMF: non-mycorrhizal fungi, AMR: arbuscular mycorrhizal response. Each value represents the mean of five replicates \pm standard error 


\section{Gas exchange parameters}

Generally, $g_{\mathrm{s}}, A$ and $E$ in mycorrhizal leaves of pepper plants were highly significant than those in non-mycorrhizal plants grown either in soil irrigated with or without sea water (Table 3), and the effect was more noticed in soil irrigated with higher concentrations of sea water. Such increases in gas exchange parameters were highly related to the degree of the mycorrhizal colonization for each treatment. Furthermore, the dependency of pepper plants on mycorrhizal fungi for improving gas exchange parameters was increased with increasing sea water concentration in soil. The differences in $g_{\mathrm{s}}, A$ and $E$ in pepper leaves were not significant between mycorrhizal plants grown in soil irrigated with $10 \%$ sea water and control treatment.

Table 3. Net photosynthetic rate (A), transpiration rate $(E)$ and stomatal conductance $\left(g_{s}\right)$ in leaves of mycorrhizal (AMF) and non-mycorrhizal (-AMF) pepper plants grown in soil irrigated with different concentrations of sea water

\begin{tabular}{|c|c|c|c|c|}
\hline \multicolumn{2}{|c|}{ Treatments } & \multicolumn{3}{|c|}{ Gas exchange parameters } \\
\hline $\begin{array}{l}\text { Sea water } \\
\text { conc. }(\%)\end{array}$ & AMF status & $\begin{array}{c}A \\
\left(\mu \mathrm{mol} \mathrm{m}^{-2} \mathrm{~s}^{-1}\right)\end{array}$ & 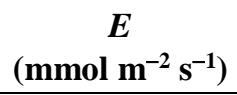 & $\begin{array}{c}g_{\mathrm{s}} \\
\left(\mathrm{mol} \mathrm{m}^{-2} \mathrm{~s}^{-1}\right)\end{array}$ \\
\hline \multirow{3}{*}{$\begin{array}{l}\text { Control } \\
(0.0)\end{array}$} & $-\mathrm{AMF}$ & $12.99 \pm 0.80^{\mathrm{C}}$ & $10.11 \pm 0.75 B^{C}$ & $0.125 \pm 0.021^{\mathrm{C}}$ \\
\hline & AMF & $15.61 \pm 0.88^{\mathrm{A}}$ & $12.24 \pm 0.74^{\mathrm{A}}$ & $0.198 \pm 0.023^{\mathrm{A}}$ \\
\hline & $\operatorname{AMR}(\%)$ & $20.17 \pm 1.01$ & $21.07 \pm 1.41$ & $58.40 \pm 3.23$ \\
\hline \multirow{3}{*}{$10 \%$} & $-\mathrm{AMF}$ & $12.98 \pm 0.69^{\mathrm{C}}$ & $09.88 \pm 0.54^{\mathrm{C}}$ & $0.111 \pm 0.020^{\mathrm{C}}$ \\
\hline & $\mathrm{AMF}$ & $15.71 \pm 0.71^{\mathrm{A}}$ & $12.20 \pm 0.70^{\mathrm{A}}$ & $0.188 \pm 0.035^{\mathrm{A}}$ \\
\hline & $\operatorname{AMR}(\%)$ & $21.03 \pm 1.24$ & $23.48 \pm 1.92$ & $69.40 \pm 3.98$ \\
\hline \multirow{3}{*}{$20 \%$} & AMF & $10.11 \pm 0.68^{\mathrm{D}}$ & $08.54 \pm 0.57^{\mathrm{CD}}$ & $0.090 \pm 0.019^{\mathrm{D}}$ \\
\hline & AMF & $13.99 \pm 0.66^{\mathrm{B}}$ & $11.88 \pm 0.70^{\mathrm{B}}$ & $0.160 \pm 0.027^{\mathrm{B}}$ \\
\hline & $\operatorname{AMR}(\%)$ & $38.38 \pm 2.99$ & $39.11 \pm 1.98$ & $77.80 \pm 3.98$ \\
\hline \multirow{3}{*}{$40 \%$} & $\mathrm{AMF}$ & $08.65 \pm 0.58^{\mathrm{E}}$ & $05.90 \pm 0.44^{\mathrm{D}}$ & $0.055 \pm 0.012^{\mathrm{E}}$ \\
\hline & $\mathrm{AMF}$ & $12.11 \pm 0.75^{\mathrm{CD}}$ & $09.24 \pm 0.80^{\mathrm{C}}$ & $0.098 \pm 0.017^{\mathrm{D}}$ \\
\hline & $\operatorname{AMR}(\%)$ & $40.00 \pm 2.87$ & $56.61 \pm 2.60$ & $78.20 \pm 3.97$ \\
\hline
\end{tabular}

Values in each column (except AMR) followed by the same letter(s) are not significantly different at $P \leq 0.05$ (Duncan's multiple range test). AMF: arbuscular mycorrhizal fungi, -AMF: non-mycorrhizal fungi, AMR: arbuscular mycorrhizal response. Each value represents the mean of five replicates \pm standard error

\section{Antioxidant enzymes}

Sea water stress significantly increased the antioxidant enzyme activities (CAT, POX and APX) in leaves of mycorrhizal and non-mycorrhizal pepper plants as compared to the control treatments (Table 4). However, mycorrhizal colonization significantly improved the contents of antioxidant enzyme activities than those in leaves of nonmycorrhizal plants, regardless of sea water treatments. This increase in antioxidant activities in leaves of pepper plants in response to mycorrhizal effects was increased with increasing sea water concentration in the soil, particularly in case of POX and APX.. On the other hand, no significant differences in APX activity was observed between mycorrhizal and non-mycorrhizal plants grown in soil irrigated with normal water. 
Table 4. Antioxidant enzymes \{catalase (CAT), Peroxidase (POX) and Ascorbate peroxidase $(A P X)$ in leaves of mycorrhizal $(A M F)$ and non-mycorrhizal (-AMF) pepper plants grown in soil irrigated with different concentrations of sea water

\begin{tabular}{|c|c|c|c|c|}
\hline \multicolumn{2}{|c|}{ Treatments } & \multicolumn{3}{|c|}{ Antioxidant enzymes } \\
\hline $\begin{array}{l}\text { Sea water } \\
\text { conc. }(\%)\end{array}$ & AMF status & $\begin{array}{c}\mathrm{CAT} \\
\left(\mu \mathrm{mol} \mathrm{H}_{2} \mathrm{O}_{2} / \mathrm{min}\right)\end{array}$ & $\begin{array}{c}\text { POX } \\
\left(\mu \mathrm{mol} \mathrm{H}_{2} \mathrm{O}_{2} / \mathrm{min}\right)\end{array}$ & $\begin{array}{c}\text { APX } \\
\text { ( } \mu \text { mol oxidized } \\
\text { ascorbate/min) }\end{array}$ \\
\hline \multirow{3}{*}{$\begin{array}{l}\text { Control } \\
(0.0)\end{array}$} & -AMF & $140 \pm 3.80^{\mathrm{E}^{*}}$ & $0.93 \pm 0.032^{\mathrm{D}}$ & $4.50 \pm 0.78^{\mathrm{D}}$ \\
\hline & AMF & $180 \pm 4.41^{\mathrm{D}}$ & $1.11 \pm 0.092^{\mathrm{CD}}$ & $4.68 \pm 0.77^{\mathrm{D}}$ \\
\hline & $\operatorname{AMR}(\%)$ & $28.6 \pm 1.07$ & $19.3 \pm 1.05$ & $04.0 \pm 0.42$ \\
\hline \multirow{3}{*}{$10 \%$} & -AMF & $145 \pm 3.69^{\mathrm{E}}$ & $1.01 \pm 0.040^{\mathrm{CD}}$ & $4.90 \pm 0.76^{\mathrm{C}}$ \\
\hline & AMF & $180 \pm 4.05^{\mathrm{F}}$ & $1.26 \pm 0.082^{\mathrm{C}}$ & $5.30 \pm 0.79^{\mathrm{BC}}$ \\
\hline & $\operatorname{AMR}(\%)$ & $26.2 \pm 1.13$ & $24.7 \pm 1.99$ & $08.0 \pm 0.55$ \\
\hline \multirow{3}{*}{$20 \%$} & -AMF & $189 \pm 4.11^{\mathrm{F}}$ & $1.30 \pm 0.18^{\mathrm{C}}$ & $5.25 \pm 0.57^{\mathrm{BC}}$ \\
\hline & $\mathrm{AMF}$ & $230 \pm 4.65^{\mathrm{C}}$ & $1.88 \pm 0.17^{\mathrm{B}}$ & $5.80 \pm 0.57^{\mathrm{B}}$ \\
\hline & $\operatorname{AMR}(\%)$ & $21.7 \pm 1.48$ & $44.6 \pm 2.55$ & $10.4 \pm 0.89$ \\
\hline \multirow{3}{*}{$40 \%$} & -AMF & $280 \pm 5.88^{\mathrm{B}}$ & $1.55 \pm 0.041^{\mathrm{B}}$ & $5.92 \pm 0.88^{\mathrm{B}}$ \\
\hline & $\mathrm{AMF}$ & $345 \pm 5.96^{\mathrm{A}}$ & $2.30 \pm 0.060^{\mathrm{A}}$ & $6.95 \pm 0.89^{\mathrm{A}}$ \\
\hline & $\operatorname{AMR}(\%)$ & $23.2 \pm 0.95$ & $48.4 \pm 2.22$ & $17.4 \pm 1.11$ \\
\hline
\end{tabular}

Values in each column (except AMR) followed by the same letter(s) are not significantly different at $P \leq 0.05$ (Duncan's multiple range test). AMF: arbuscular mycorrhizal fungi, -AMF: non-mycorrhizal fungi, AMR: arbuscular mycorrhizal response. Each value represents the mean of five replicates \pm standard error

\section{Mycorrhizal colonization levels}

Mycorrhizal colonization levels (frequency (F\%), intensity (M\%) of mycorrhizal colonization and arbuscular development (A\%)) in root tissues of pepper plants were significantly affected by sea water stress in soil. Both intensity of mycorrhizal colonization (M\%) and arbuscular frequency (A\%) were significantly decreased in pepper root tissues with increasing concentration of sea water in soil (Table 5). On the other hand, no significant differences were observed in the frequency of mycorrhizal colonization $(\mathrm{F} \%)$ in root tissues between mycorrhizal plants irrigated with or without sea water concentration. On the contrary; no significant differences were observed in the intensity of mycorrhizal colonization (M\%) between AMF plants grown either in soil irrigated with $10 \%$ sea water and control treatment. No mycorrhizal colonization was observed in the non-inoculated pepper plants.

\section{Nutrient content}

Increasing sea water concentration in soil significantly reduced $\mathrm{N}, \mathrm{P}, \mathrm{Mg}, \mathrm{Ca}$ and $\mathrm{K}$ concentrations, but increased sodium in the shoots of mycorrhizal and non-mycorrhizal pepper plants. However, P, N, K, Ca and Mg contents in shoot tissues of the AM plants, in most cases, were significantly greater than those in non-mycorrhizal pepper plants grown in soil irrigated with or without sea water concentrations (Table 6). Such stimulations in nutrients content in response to the mycorrhizal effects were highly increased with increasing sea water concentration in the soil. AM-inoculated plants exhibited reduction in $\mathrm{Na}$ concentration in shoot tissues compared to non-mycorrhizal 
control plants in either soil irrigated with different concentration of sea water and control treatment (Table 6). The rate of reduction in $\mathrm{Na}$ content in response to mycorrhizal effects (AMR) was increased highly with increasing sea water concentration in the soil. On the other hand, no significant differences in Mg content in shoot tissues were observed between mycorrhizal and non-mycorrhizal pepper plants at control and $20 \%$ sea water treatments

Table 5. Frequency of mycorrhizal infection ( $F \%)$ Intensity of mycorrhizal colonization ( $M$ $\%)$ and arbuscular frequency $(A \%)$ in the root tissues of mycorrhizal (AMF) and nonmycorrhizal (-AMF) pepper plants grown in soil irrigated with different concentrations of sea water

\begin{tabular}{c|c|c|c|c}
\hline \multicolumn{2}{c|}{ Treatments } & \multicolumn{2}{c}{ Level of mycorrhizal colonization (\%) } \\
\hline $\begin{array}{c}\text { Sea water } \\
\text { conc. (\%) }\end{array}$ & AMF status & $\mathbf{F}$ & $\mathbf{M}$ & $\mathbf{A}$ \\
\hline $\begin{array}{c}\text { Control } \\
(0.0)\end{array}$ & $-\mathrm{AMF}$ & $0.0^{\mathrm{C}}$ & $0.0^{\mathrm{C}^{*}}$ & $0.0^{\mathrm{C}^{*}}$ \\
\hline \multirow{2}{*}{$10 \%$} & AMF & $95.2 \pm 4.11^{\mathrm{A}}$ & $80.3 \pm 3.99^{\mathrm{A}}$ & $61.8 \pm 2.63^{\mathrm{A}}$ \\
\hline \multirow{2}{*}{$20 \%$} & $-\mathrm{AMF}$ & $0.0^{\mathrm{C}^{*}}$ & $0.0^{\mathrm{C}^{*}}$ & $0.0^{\mathrm{C}^{*}}$ \\
& AMF & $93.7 \pm 4.01^{\mathrm{A}}$ & $75.6 \pm 3.540^{\mathrm{A}}$ & $57.0 \pm 2.47^{\mathrm{A}}$ \\
\hline \multirow{2}{*}{$40 \%$} & $-\mathrm{AMF}$ & $0.0^{\mathrm{C}^{*}}$ & $0.0^{\mathrm{C}^{*}}$ & $0.0^{\mathrm{C}^{*}}$ \\
& AMF & $82.8 \pm 3.58^{\mathrm{A}}$ & $71.3 \pm 3.54^{\mathrm{AB}}$ & $48.7 \pm 1.99^{\mathrm{B}}$ \\
\hline
\end{tabular}

Values in each column (except AMR) followed by the same letter(s) are not significantly different at $P \leq 0.05$ (Duncan's multiple range test). AMF: arbuscular mycorrhizal fungi, -AMF: non-mycorrhizal fungi. Each value represents the mean of five replicates \pm standard error

Table 6. Nutrients $(\mathrm{N}, \mathrm{P}, \mathrm{K})$ and minerals $(\mathrm{Ca}, \mathrm{Mg}, \mathrm{Na})$ content in leaves of mycorrhizal $(A M F)$ and non-mycorrhizal (-AMF) pepper plants grown in soil irrigated with different concentrations of sea water

\begin{tabular}{|c|c|c|c|c|c|c|c|}
\hline \multicolumn{2}{|c|}{ Treatments } & \multicolumn{5}{|c|}{ Nutrients and minerals content $\left[\mathrm{mg} \mathrm{g}^{-1}(\mathrm{Dwt})\right]$} & \multirow[b]{2}{*}{$\mathbf{N a}$} \\
\hline Water status & AMF status & $\mathbf{N}$ & $\mathbf{P}$ & $\mathbf{K}$ & $\mathbf{C a}$ & Mg & \\
\hline \multirow{3}{*}{$\begin{array}{c}\text { Control } \\
(0.0)\end{array}$} & $-\mathrm{AMF}$ & $2.80 \pm 0.17^{\mathrm{C}}$ & $0.17 \pm 0.052^{\mathrm{B}}$ & $38.9 \pm 1.55^{\mathrm{B}}$ & $16.2 \pm 0.88^{\mathrm{AB}}$ & $11.1 \pm 0.55^{\mathrm{A}}$ & $12.0 \pm 0.111^{\mathrm{E}}$ \\
\hline & AMF & $3.18 \pm 0.18^{\mathrm{A}}$ & $0.30 \pm 0.081^{\mathrm{A}}$ & $42.2 \pm 1.68^{\mathrm{A}}$ & $17.4 \pm 0.89^{\mathrm{A}}$ & $11.5 \pm 0.55^{\mathrm{A}}$ & $11.3 \pm 0.17^{\mathrm{E}}$ \\
\hline & $\operatorname{AMR}(\%)$ & $13.6 \pm 1.11$ & $82.4 \pm 3.22$ & $9.65 \pm 0.44$ & $7.40 \pm 0.54$ & $3.60 \pm 0.042$ & $-05.83 \pm 0.44$ \\
\hline \multirow{3}{*}{$10 \%$} & -AMF & $2.81 \pm 0.15^{\mathrm{C}}$ & $0.16 \pm 0.045^{\mathrm{B}}$ & $34.2 \pm 1.32^{\mathrm{C}}$ & $13.7 \pm 0.77^{\mathrm{C}}$ & $10.8 \pm 0.59^{\mathrm{B}}$ & $19.6 \pm 0.98^{\mathrm{C}}$ \\
\hline & AMF & $3.20 \pm 0.15^{\mathrm{A}}$ & $0.30 \pm 0.084^{\mathrm{A}}$ & $39.5 \pm 1.44^{\mathrm{AB}}$ & $15.1 \pm 0.71^{\mathrm{B}}$ & $11.5 \pm 0.61^{\mathrm{A}}$ & $16.6 \pm 0.88^{\mathrm{D}}$ \\
\hline & $\operatorname{AMR}(\%)$ & $13.9 \pm 1.051$ & $87.5 \pm 3.85$ & $15.5 \pm 0.88$ & $9.56 \pm 0.52$ & $6.48 \pm 0.098$ & $-15.31 \pm 1.04$ \\
\hline \multirow{3}{*}{$20 \%$} & -AMF & $2.45 \pm 0.14^{\mathrm{D}}$ & $0.12 \pm 0.034^{\mathrm{C}}$ & $26.6 \pm 0.99^{\mathrm{E}}$ & $12.05 \pm 0.68^{\mathrm{C}}$ & $08.7 \pm 0.33^{\mathrm{C}}$ & $22.2 \pm 1.05^{\mathrm{B}}$ \\
\hline & $\mathrm{AMF}$ & $3.01 \pm 0.15^{\mathrm{B}}$ & $0.27 \pm 0.077^{\mathrm{AB}}$ & $32.2 \pm 1.01^{\mathrm{C}}$ & $13.75 \pm 0.66^{\mathrm{C}}$ & $09.6 \pm 0.37^{\mathrm{C}}$ & $18.5 \pm 1.55^{\mathrm{CD}}$ \\
\hline & $\operatorname{AMR}(\%)$ & $22.9 \pm 1.55$ & $125 \pm 5.14$ & $21.1 \pm 0.98$ & $14.1 \pm 1.01$ & $10.3 \pm 0.99$ & $-16.67 \pm 1.85$ \\
\hline \multirow{3}{*}{$40 \%$} & -AMF & $2.05 \pm 0.091^{\mathrm{E}}$ & $0.09 \pm 0.004^{\mathrm{D}}$ & $22.7 \pm 0.57^{\mathrm{E}}$ & $7.02 \pm 0.33^{\mathrm{F}}$ & $06.5 \pm 0.12^{\mathrm{D}}$ & $28.9 \pm 1.74^{\mathrm{A}}$ \\
\hline & AMF & $2.92 \pm 0.10^{\mathrm{BC}}$ & $0.25 \pm 0.014^{\mathrm{B}}$ & $29.9 \pm 0.59^{\mathrm{D}}$ & $9.00 \pm 0.571^{\mathrm{D}}$ & $08.1 \pm 0.15^{\mathrm{C}}$ & $21.3 \pm 1.88^{\mathrm{B}}$ \\
\hline & $\operatorname{AMR}(\%)$ & $42.4 \pm 2.05$ & $178 \pm 7.40$ & $31.7 \pm 1.41$ & $28.2 \pm 1.33$ & $24.6 \pm 1.99$ & $-26.30 \pm 2.11$ \\
\hline
\end{tabular}

Values in each column (except AMR) followed by the same letter(s) are not significantly different at $P \leq 0.05$ (Duncan's multiple range test). AMF: arbuscular mycorrhizal fungi, -AMF: non-mycorrhizal fungi, AMR: arbuscular mycorrhizal response. Each value represents the mean of five replicates \pm standard error 


\section{Discussion}

Salinity of soil is one of the severe abiotic stress problems particularly in arid and semi-arid area like Saudi Arabia. It directly negatively affecting the majority of arable lands worldwide, limiting the growth and production of most of the economically important crop, vegetable and horticulture plants (Giri et al., 2003; Al-Karaki, 2006; Kaya et al., 2009; Ibrahim et al., 2011; Abdel-Fattah and Asrar, 2012; Asrar et al., 2014; Elhindi et al., 2017). Augmenting salt concentration in soil decreases the plant ability to absorb water, negatively affect all metabolic processes and osmotic balance, nutrient absorption, water relations and net photosynthetic rate. All of these results adversely affecting plant growth and productivity (Ojala et al., 1983; Zuccarini, 2007; Scharnagl et al., 2018).

It is evident from the present investigation that sea water stress significantly decreased of estimated growth parameters of mycorrhizal and non-mycorrhizal pepper plants compared to the control plants. However, mycorrhizal fungi improved growth and biomass of pepper plants grown in either sea water stressed or control soils when comparing with non-mycorrhizal plants. The dependency of pepper plants on mycorrhizal fungi was highly increased with increasing sea water concentration soil. These results are entirely consistent with earlier studies on other crop and vegetable plant species (Giri et al., 2007; Al-Amri et al., 2013; Sheng et al., 2013). Enhancement of growth in mycorrhizal pepper plants irrigated with different concentrations of sea water has been related partially to mycorrhizal enhancement of host plant $\mathrm{P}, \mathrm{N}$ and $\mathrm{K}$ nutrition (Poss et al., 1985; Garg and Chandel, 2011; Evelin et al., 2012).

Interestingly, $\mathrm{AM}$ pepper plants had higher $\mathrm{K}, \mathrm{Ca}, \mathrm{P}$ and $\mathrm{N}$ contents than nonmycorrhizal plants grown at sea water stress treatment. In this connection, pepper plant tolerance to sea water stress was improved highly by mycorrhizal fungi. The obtained results suggested that improving growth of pepper plants duo to mycorrhizal colonization is a manifest of increased nutrients content and maintaining favorable ionic ratios than non-mycorrhizal pepper plants. These results are confirmed by the most previous studies (Kaya et al., 2009; Kumar et al., 2010; Scharnagl et al., 2018). Furthermore, improved P, N, K and Ca contents by mycorrhizal fungi in pepper plants grown under sea water stress conditions may contribute to the maintenance of vacuolar membrane integrity and facilitate the compartmentalization of $\mathrm{Na}$ ions with vacuoles (Cantrell and Linderman, 2001). Preventation of $\mathrm{Na}$ ion from interfering in metabolic pathways of growth and yield, thereby mitigated the toxicity of sea water stress (Poss et al., 1985; Abdel-Fattah and Asrar, 2012). Lower Na in the mycorrhizal plants than nonmycorrhizal plants may be explained by the dilution effect due to growth enhancement (Giri and Mukherjee, 2004; Al-Karaki, 2006). In addition, Mycorrhizal inoculation can increase $\mathrm{K}^{+}$absorption under sea water stress conditions. The higher $\mathrm{K}^{+}: \mathrm{Na}^{+}$ratio helps not only to prevent the disruption of various K-mediated enzymatic processes and inhibition of protein synthesis but also are beneficial in influencing the ionic balance of the cytoplasm or $\mathrm{Na}^{+}$efflux from plants (Colla et al., 2008; Zuccarini and Okurowska, 2008).

Photosynthetic pigments like chlorophyll have been proposed as one of the most parameters of salt tolerance in plants (Sirivastava et al., 1998) and also carotenoids are responsible for reducing of single oxygen (Bourgou et al., 2012). In this connection, it is evident from the present investigation that the photosynthetic pigments in leaves of mycorrhizal pepper plants were significantly higher than those in non-mycorrhizal plants grown in soil irrigated with sea water. The dependency of pepper plants on AM 
fungi was increased highly with increasing sea water concentration in soil. These results are in line with results of Elhindi et al. (2017) and Scharnagl et al. (2018). Furthermore, mycorrhiza improving $\mathrm{Mg}^{++}$support a higher chlorophyll concentration. Effective $\mathrm{Mg}^{++}$ uptake helps by increasing the chlorophyll content and hence stimulating photosynthetic efficiency and plant growth (Camprubi et al., 2012; Metwally and Abdelhameed, 2018). Of particular interest in this study that $g_{s}, P_{N}$ and $E$ were highly significant in the AM pepper plants than in the non-mycorrhizal plants grown in soil irrigated with or without different concentrations of sea water. Such increased in the contents of gas water exchange were linked to the degree of mycorrhizal colonization. These results are in the same line of those obtained by Auge et al. (2008), Abdel-Fattah et al. (2013), Metwally and Abdelhameed (2018).

Sea water stress in soil not only affect the growth and production of pepper plant but also the levels of mycorrhizal colonization in associated pepper plants. These results were in agreement with the previous findings (Aroca et al., 2013; Abdel-Fattah et al., 2016; Elhindi et al., 2017). Based on the previous results of Jiang and Zhang (2002), who reported that antioxidant enzymes play an important role in scavenging of reactive oxygen species (ROS) and hence averting the oxidative stress induced damaging effects on several sensitive molecules like nucleic acids, proteins and lipids The present study demonstrated that the activities of CAT, POX and APX in mycorrhizal plants were significantly higher than in non-mycorrhizal pepper plants grown either in soil irrigated with or without sea water. Such stimulation in antioxidant activities in response to the mycorrhizal effect were significantly increased with increasing sea water concentration in soil. In this connection, several investigators reported that mycorrhizal symbiosis helps plants to alleviate or reduced salt stress by enhancing the activities of antioxidant enzymes (Tang et al., 2009; Metwally and Abdelhameed, 2018).

\section{Conclusion}

Arbuscular mycorrhizal colonization has a great contribution from pepper plant to alleviate salinity stress imposed by irrigation with different concentrations of sea water through improving growth, increasing nutrient contents, stimulating gas exchange parameters, presentation of $\mathrm{Na}^{+}$content and transfer by the roots to the shoots and some metabolic contents of pepper plants. These benefits in response to mycorrhizal inoculation were greatly increased with increasing sea water concentration in soil, suggesting that pepper plants was highly depended on mycorrhizal fungi particularly at higher concentration of sea water. However, more investigations are required to explain in details the relationship between the molecular of AM efficiency for plant growth and other metabolic activates in different varieties of plants under salinity stress conditions.

Acknowledgements. The author would like to thank the Deanship of Scientific Research, Shaqra University, Saudi Arabia for supporting this work.

Author contribution. The author designed and formed the experiments and analyzed the results. In addition, the author wrote, edited and revised the paper and approved the final version of the manuscript to be published. 


\section{REFERENCES}

[1] Abdel-Fattah, G. M., Asrar, A. A. (2012): Arbuscular mycorrhizal fungal application to improve growth and tolerance of wheat (Triticum aestivum L.) plants grown in saline soil. - Acta Physiol Plantarum 34: 267-277.

[2] Abdel-Fattah, G. M., Ibrahim, A. H., Al-Amri, S. M., Shoker, A. E. (2013): Synergistic effect of arbuscular mycorrhizal fungi and spermine on amelioration of salinity stress of wheat (Triticum aestivum L. cv. gimiza). - Aust. J. Crop Sci. 7: 1525-1532.

[3] Abdel-Fattah, G. M., Rabie, G. H., Lamis, D., Rabab, A. M. (2016): The impact of arbuscular mycorrhizal fungi on growth and physiological parameters of cowpea plants grown under salt stress conditions. - Int. J. Appl. Sci. Biotechnology 4: 372-379.

[4] Abdel-Ghani, A. H. (2009): Response of wheat varieties from semi-arid regions of Jordan to salt stress. - J. Agron. Crop Science 195: 55-65.

[5] Aebi, H. (1983): Catalase. - In: Bergmeyer, H. (Ed.), Methods of Enzymatic Analysis. Weinheim-Verlagchemie, Weinheim, pp. 273-286.

[6] Al-Amri, S. M., Al-Whaibi, M. H., Abdel-Fattah, G. M., Siddiqui, M. H. (2013): Role of mycorrhizal fungi in tolerance of wheat genotypes to salt stress. - African J. Microbiol. Res. 7: 1286-1295.

[7] Al-Karaki, G. N. (2006): Nursery inoculation of tomato with arbuscular mycorrhizal fungi and subsequent performance under irrigation with saline water. - Scientia Horticulturae 109: 1-7.

[8] Al-Karaki, G. N., Hammad, R., Rusan, M. (2001): Response of two tomato cultivars differing in salt tolerance to inoculation with mycorrhizal fungi under salt stress. Mycorrhiza 11: 43-47.

[9] Aroca, R., Ruiz-Lozano, J. M., Lopez-Raez, J. A. (2013): Arbuscular mycorrhizal symbiosis influences strigolactone production under salinity and alleviates salt stress in lettuce plants. - J. Plant Physiol. 170: 47-55.

[10] Asrar, A., Abdel-Fattah, G., Elhindi, K., Abdel-Salam, E. (2014): The impact of arbuscular mychorrhizal fungi in improving growth, flower yield and tolerance of kalanchoe (Kalanchoe blossfeldiana Poelin) plants grown in NaCl-stress conditions. Journal of Food, Agriculture \& Environment 12: 105-112.

[11] Auge, R. M., Toler, H. D., Sams, C. E., Nasim, G. (2008): Hydraulic conductance and water potential gradients in squash leaves showing mycorrhiza-induced increases in stomatal conductance. - Mycorrhiza 18: 115-121.

[12] Bourgou, S., Bettaie, I., Hamrouni, I., Marzouk, B. (2012): Effect of $\mathrm{NaCl}$ on fatty acids, phenolics and antioxidant activity of Nigella sativa organs. - Acta Physiol. Plantarum 34: 379-386.

[13] Camprubi, A., Abril, M., Estaun, V., Calvet, C. (2012): Contribution of arbuscular mycorrhizal symbiosis to the survival of psammophilic plants after sea water flooding. Plant Soil 35: 97-107.

[14] Cantrell, I. C., Linderman, R. G. (2001): Preinoculation of lettuce and onion with VA mycorrhizal fungi reduces deleterious effects of soil salinity. - Plant and Soil 233: 269281.

[15] Colla, G., Rouphael, Y., Cardarelli, M., Tullio, M., Rivera, C. M., Rea, E. (2008): Alleviation of salt stress by arbuscular mycorrhizal in Zucchini plants grown at low and high phosphorus concentration. - Biology and Fertility of Soils 44: 501-509.

[16] Daei, G., Ardekani, M. R., Rejali, F., Teimuri, S., Miransari, M. (2009): Alleviation of salinity stress on wheat yield, yield components and nutrient uptake using arbuscular mycorrhizal fungi under field conditions. - J. Plant Physiol. 166: 617-625.

[17] Elhindi, K. M., Sharaf El-Din, A., Elgorban, A. M. (2017): The impact of arbuscular mycorrhizal fungi in mitigating salt-induced adverse effect in sweet basil (Ocimum basilicum L.). - Saudi Journal of Biological Science 24: 170-179. 
[18] Evelin, H., Kapoor, R., Giri, B. (2009): Arbuscular mycorrhizal fungi in alleviation of salt stress: a review. - Ann Botany 104: 1263-1280.

[19] Evelin, H., Giri, B., Kapoor, R. (2012): Contribution of Glomus intraradices inoculation to nutrient acquisition and mitigation of ionic imbalance in NaCL-stressed Trigonella graecum. - Mycorrhiza 22: 203-217.

[20] Gajewska, E., Sklodowska, M. (2007): Effect of nickel on ROS content and antioxidative enzyme activities in wheat leaves. - Bio Metals 20: 27-36.

[21] Garg, N., Chandel, S. (2011): Effect of mycorrhizal inoculation on growth, nitrogen fixation and nutrient uptake in Cicer arietinum L. under salt stress. - Turk. J. Agric. 35: 205-214.

[22] Gerdemann, J. W., Nicolson, T. H. (1936): Spores of mycorrhizal endogone species extracted from soil by wet sieving and decanting. - Trans. Brit. Mycol. Soc. 46: 235-244.

[23] Giri, B., Mukherjee, K. G. (2004): Mycorrhizal inoculant alleviates salt stress in Sesbania aegyptiaca and Sesbania grandiflora under field conditions: evidence for reduced sodium and improved magnesium uptake. - Mycorrhiza 14: 307-312.

[24] Giri, B., Kapoor, R., Mukerji, K. G. (2003): Influence of arbuscular mycorrhizal fungi and salinity on growth, biomass and mineral nutrition of Acacia auriculiformis. - Biology and Fertility of Soils 38: 170-175.

[25] Giri, B., Kapoor, R., Mukerji, K. G. (2007): Improved tolerance of Acacia nilotica to salt stress by arbuscular mycorrhiza, Glomus fasciculatum, may be partly related to elevated $\mathrm{K}^{+} / \mathrm{Na}^{+}$ratios in root and shoot tissues. - Microbial Ecology 54: 753-760.

[26] Ibrahim, H. A., Abdel-Fattah, G. M., Eman, F. M., AbdEl_Aziz. M. H., Shohr, A. E. (2011): Arbuscular mycorrhizal fungi and spermine alleviate the adverse effects of salinity stress on electrolyte leakage and productivity of wheat plants. - Phyton-Ann Rel Bot. 51: 261-276.

[27] Jackson, M. L.: Soil Chemical Analysis. - Prentice Hall of India Ltd., New Delhi.

[28] Jiang, M., Zhang, J. (2002): Water stress-induced abscissic acid accumulation triggers the increased generation of reactive oxygen species and up-regulates the activities of antioxidant enzymes in maize-leaves. - Journal of Experimental Botany 53: 2401-2410.

[29] Juniper, S., Abbott, L. K. (1993): Vesicular-arbuscular mycorrhizas and soil salinity. Mycorrhiza 4: 45-57.

[30] Juniper, S., Abbott, L. K. (2006): Soil salinity delays germination and limits growth of hyphae from propagules of arbuscular mycorrhizal fungi. - Mycorrhiza 16: 371-379.

[31] Kaya, C., Ashraf, M., Sonmez, O., Aydemir, S., Tuna, A. L., Cullu, M. A. (2009): The influence of arbuscular mycorrhizal colonization on key growth parameters and fruit yield of pepper plants grown at high salinity - Scientia Horticulturae 121: 1-6.

[32] Kumar, A., Sharma, S., Mishra, S. (2010): Influence of arbuscular mycorrhizal (AM) fungi and salinity on seedling growth, solute accumulation and mycorrhizal dependency of Jatropha curcas L. - J Plant Growth Regul. 29: 297-306.

[33] Metwally, R., Abdelhameed, R. (2018): Synergistic effect of arbuscular mycorrhizal fungi on growth and physiology of salt-stressed Trigonella foenum-graecum plants. Biocatalysis and Agricultural Biotechnology 16: 538-544.

[34] Menge, J. A., Johnson, E. L. V., Platt, R. G. (1978): Mycorrhizal dependency of several citrus cultivars under three nutrient regimes. - New Phytol. 81: 553-559.

[35] Nakano, Y., Asada, K. (1981): Hydrogen peroxide is scavenged by ascorbate-specific peroxidase in spinach chloroplasts. - Plant Cell Physiol. 22: 867-880.

[36] Nelson, D. W., Sommers, L. E. (1973): Determination of total nitrogen in plant material. - Agro. J. 65: 109-112.

[37] Ojala, J. C., Jarrel, W. M., Menge, J. A., Johnson, E. L. V. (1983): Influence of mycorrhizal fungi on the mineral nutrition and yield of onion in saline soil. - Agron J. 75: 255-259. 
[38] Phillips, J. M., Hayman, D. S. (1970): Improved procedures for clearing roots and staining parasitic and vesicular-arbuscular mycorrhizal fungi for rapid assessment of infection. - Trans. Brit. Mycol. Soc. 55: 158-161.

[39] Pond, E. C., Menge, J. A., Jarrell, W. M. (1984): Improved growth of tomato in salinized soil by vesicular arbuscular mycorrhizal fungi collected from saline sites - Mycologia 76: 74-84.

[40] Poss, J. A., Pond, E. C., Menge, J. A., Jarrell, W. M. (1985): Effect of salinity on mycorrhizal onion and tomato in soil with and without additional phosphate - Plant and Soil 88: 307-319.

[41] Scharnag, K., Sanchez, V., Wettberg, E. (2018): The impact of salinity on mycorrhizal colonization of a rare legume, Galactia smallii in south Florida pine rocklands. - BNC Res. Notes 11: 2-5.

[42] Sheng, M., Lalande, R., Hamel, C., Zladi, N. (2013): Effect of long-term tillage and mineral phosphorus fertilization on arbuscular mycorrhizal fungi in a humid continental zone of Eastern Canada. - Plant Soil 369: 599-613.

[43] Sirivastava, T. P., Gupta, S. C., Lal, P, Muralia N, Kumar, N. (1998): Effect of salt stress on physiological and biochemical parameters of wheat. - Ann Arid Zone 27: 197-204.

[44] Tang, M., Chen, H., Huang, J. C., Tian, Z. Q. (2009): AM fungi effects on the growth and physiology of Zea mays seedlings under diesel stress. - Soil Biol. Biochem. 41: 936-940.

[45] Trouvelot, A., Kough, J., Gianinazzi-Pearson, V. (1986): Evaluation of VA Infection Levels in Root Systems. Research for Estimation Methods Having a Functional Significance. - In: Gianinazzi-Pearson, V., Gianinazzi, S. (eds.) Physiological and Genetical Aspects of Mycorrhizae. INRA Press, Paris, pp. 217-221.

[46] Wu, Q. S., Zon, Y. N., Liu, W., Ye, X. E., Zai, H. E., Zhao, L. J. (2010): Alleviation of salt stress in citrus seedlings inoculated with mycorrhiza: changes in leaf antioxidant defense systems. - Plant Soil Environ. 56: 470-475.

[47] Zuccarini, P. (2007): Mycorrhizal infection ameliorates chlorophyll content and nutrient uptake of lettuce exposed to saline irrigation. - Plant, Soil and Environment 53: 283-289.

[48] Zuccarini, P., Okurowska, P. (2008): Effects of mycorrhizal colonization and fertilization on growth and photosynthesis of sweet basil under salt stress. - Journal of Plant Nutrition 31: 497-513. 